\title{
THE INTERNATIONAL LAW FRAMEWORK REGULATING THE USE OF ARMED DRONES*
}

\author{
Christof Heyns, Dapo Akande, Lawrence Hill-Cawthorne and \\ THOMPSON CHENGETA**
}

\begin{abstract}
This article provides a holistic examination of the international legal frameworks which regulate targeted killings by drones. The article argues that for a particular drone strike to be lawful, it must satisfy the legal requirements under all applicable international legal regimes, namely: the law regulating the use of force (ius ad bellum); international humanitarian law and international human rights law. It is argued that the legality of a drone strike under the ius ad bellum does not preclude the wrongfulness of that strike under international humanitarian law or international human rights law, and that since those latter obligations are owed to individuals, one State cannot consent to their violation by another State. The article considers the important legal challenges that the use of armed drones poses under each of the three legal frameworks mentioned above. It considers the law relating to the use of force by States against non-State groups abroad. This part examines the principles of self-defence and consent, in so far as they may be relied upon to justify targeted killings abroad. The article then turns to some of the key controversies in the application of international humanitarian law to drone strikes. It examines the threshold for non-international armed conflicts, the possibility of a global non-international armed conflict and the question of who may be targeted in a non-international armed conflict. The final substantive section of the article considers the nature and application of the right to life in armed conflict, as well as the extraterritorial application of that right particularly in territory not controlled by the State conducting the strike.
\end{abstract}

* This is a much expanded version of a report presented by Christof Heyns to the UN General Assembly on 25 October 2013, A/68/30532, available at <http://www.ohchr.org/Documents/ HRBodies/HRCouncil/RegularSession/Session23/A-HRC-23-47_en.pdf $>$ or $<$ http://www.un.org/ $\mathrm{ga} / \mathrm{search} /$ view_doc.asp?symbol=A\%2F68\%2F382\&Submit=Search\&Lang=E $>$. We would like to thank the participants at the expert meeting on 'Armed Drones and the Right to Life' hosted by the Oxford Institute for Ethics, Law and Armed Conflict and the Oxford Martin Programme on Human Rights for Future Generations in July 2013.

** Professor of Human Rights Law, University of Pretoria and United Nations Special Rapporteur on extrajudicial, summary or arbitrary executions; Professor of Public International Law, University of Oxford, Co-Investigator on the Individualization of War Project funded by the European Research Council and Yamani Fellow, St Peter's College, Oxford. Dapo is grateful to Franziska Oehm for her assistance with the preparation of this article; Lecturer in Law, University of Reading; Researcher, Institute for International and Comparative Law in Africa, University of Pretoria and Lecturer of Law at Midlands State University, Zimbabwe. 
Keywords: classification of conflicts, consent and use of force, direct participation in hostilities, drones, extraterritorial application of right to life, human rights in armed conflict, non-international armed conflicts, self-defence, self-defence and non-State groups.

\section{INTRODUCTION}

States have and will continue to develop new methods of employing lethal force. On the horizon, for example, are developments in autonomous robotic systems ${ }^{1}$ and nano- and biotechnology, ${ }^{2}$ which raise a plethora of complex issues that the international community must address in coordinated ways. Armed drones (or 'unmanned aerial vehicles', or UAVs, fitted with weapons), called here merely 'drones', have moved from the horizon into the realm of the known. The attraction of drones is clear-in particular, they provide a strategic advantage of the deployment of deadly force against a remote target without exposing one's own forces to risks.

During the past decade or so, many States have become increasingly reliant on unmanned systems and in particular drones to deliver force in the context of military operations. ${ }^{3}$ By the end of 2013, the US, for example, had over 20,000 unmanned systems. ${ }^{4}$ Drones have not only been used by the UK, USA, Israel and the North Atlantic Treaty Organisation in operations outside their territory (in Afghanistan, Pakistan, Yemen, Libya, Iraq, Somalia, Gaza and Syria), they have also been used by Pakistan, Iraq and Nigeria within their own territory. ${ }^{5}$

\footnotetext{
1 Heyns Report on Lethal Autonomous Robots, 9 April 2013, A/HRC/23/47, available at $<$ http://www.ohchr.org/Documents/HRBodies/HRCouncil/RegularSession/Session23/A-HRC-2347_en.pdf $\geq$.

2 See $\bar{F}$ Simonis and S Schilthuizen, Nanotechnology: innovation opportunities for tomorrow's defence (TNO Science and Industry 2006).

3 PW Singer, Wired for War (Penguin 2009); P Rogers, Unmanned Air Systems: The Future of Air \& Sea Power? (Institut Français des Relations Internationales 2014); J Gertler, U.S. Unmanned Aerial Systems (Congressional Research Service 2012) 3; US Department of Defense, 'Unmanned Systems Integrated Roadmap', FY2013-2038 (2013) 19, available at <http://www.defense.gov/ Portals/1/Documents/pubs/DOD-USRM-2013.pdf>. See R O'Gormann and C Abbott, Remote control war: Unmanned combat air vehicles in China, India, Israel, Iran, Russia and Turkey (Open Briefing, London 2013) available at <http://issuu.com/openbriefing/docs/remote_ control_war>; S Joshi and A Stein, 'Emerging Drone Nations' (2013) 55 Survival 53; G Taylor, 'U.S. intelligence warily watches for threats to U.S. now that 87 nations possess drones', The Washington Times, 10 November 2013, available at <http://www.washingtontimes.com/news/ 2013/nov/10/skys-the-limit-for-wide-wild-world-of-drones/?page=all>.

4 See PW Singer, 'The Predator Comes Home: A Primer on Domestic Drones, their Huge Business Opportunities, and their Deep Political, Moral, and Legal Challenges', Brookings Institution, 8 March 2013, available at <http://www.brookings.edu/research/papers/2013/03/08drones-singer>; US Department of Defense, 'Task Force Report: The Role of Autonomy in DoD Systems' (Defense Science Board, July 2012) 78, available at <http://www.acq.osd.mil/dsb/ reports/AutonomyReport.pdf> .

5 See UN Doc A/68/389, paras 25-40 and C Dillow, 'All of These Countries Now Have Armed Drones', Fortune, 12 February 2016, available at <http://fortune.com/2016/02/12/these-countrieshave-armed-drones $>$.
} 
In Pakistan, for example, it was reported that between 2004 and 2014, a minimum of 2,300 people were killed by US drone strikes. ${ }^{6}$ Of that number, 420 have been identified as civilians, amongst which were approximately 150 children. ${ }^{7}$ In Yemen, at least 300 people have been killed to date, amongst them a minimum of 30 civilians. $^{8}$

In spite of concerns that have been raised about them, drones are clearly here to stay. Indeed, it might even be said that unmanned systems, including drones, are the future of warfare. There is broad agreement that drones per se are not illegal weapons, in the sense of possessing characteristics that necessarily violate rules of international law. ${ }^{9}$ However, despite the fact that drones are now an established technology, there is, in some respects, a lack of consensus on how to apply to drones the various rules of international law that regulate the use of lethal force, notably the ius ad bellum, international humanitarian law and international human rights law. It is the aim of this article to contribute toward clarifying the application of these different rules to drone warfare. In particular, this article will explore a number of contested issues that arise in these three areas of international law and the implications of these controversies for the regulation of armed drones.

Drones can be expected to become increasingly sophisticated and smaller in form, as well as become cheaper and therefore more accessible. In addition, the technological skills needed to operate these systems are becoming readily available in different parts of the world. Drones are likely to form part of the arsenals of an increasing number of States that may be able to deploy such weapons across international borders in relatively non-intrusive ways, both on traditional 'battlefields' and for the purposes of pursuing targets far removed from what would traditionally be seen as the 'zone of hostilities'. Some States may also wish to use armed drones in domestic law enforcement contexts, such as for border patrols, operations against organized crime, and crowd control in demonstrations. Armed drones are also reportedly already within the arsenal of some non-State actors. In sum, the number of States and actors with the capacity to use drones is likely to increase significantly in the near future, underscoring the need for greater consensus on the terms of their use.

One of the most important consequences of the expanding use of drones is that targeted killing across borders appears to be easier than in the past. This creates the potential for undermining the role that State sovereignty, irrespective of the controversies that admittedly surrounds this concept, plays in sustaining the international security system. Indeed, the ready availability of drones may lead to situations where States that perceive their interests to

\footnotetext{
${ }^{6}$ The Bureau of Investigative Journalism, Covert Drone War (2014) available at $<$ http://www. thebureauinvestigates.com/category/projects/drones/ $>$. $\quad 7$ ibid. $\quad{ }^{8}$ ibid.

9 This is not the case, for example, with lethal autonomous robots. See Heyns Report (n 1).
} 
be threatened increasingly engage in low-intensity, but drawn-out, applications of force that know few geographical or temporal boundaries.

This would run counter to the notion that war-and the transnational use of force in general - is an exceptional situation of limited duration and scope, and that there should be a time for healing and recovery following conflict. An approach in terms of which peacetime is the exception, and armed conflict the norm, could have far-reaching consequences for the protection of the right to life. The laws specifically designed for wartime, international humanitarian law (IHL), offer less protection of life than does the default regime of international human rights law (IHRL), precisely because war is seen as an exception. ${ }^{10}$ To the extent that war becomes the norm, the lower level of protection of life offered by IHL risks becoming seen as the default regime.

\section{THE APPLICABLE LEGAL FRAMEWORKS AND THE RELATIONSHIP BETWEEN THEM}

A number of substantive areas of international law have a direct bearing on the legality of the use of armed drones. The two most directly relevant to the protection of the right to life are international humanitarian law (IHL) and international human rights law (IHRL). Each of these regimes balances, albeit to different degrees, State security concerns on the one hand and the protection of individuals (including the protection of life) on the other. The third area of international law of particular importance to the use of drones is the law governing the use of force by one State on another State's territory (ius ad bellum). These ad bellum rules form the cornerstone of the international security system and will determine the legality of the inter-State use of armed drones.

The law on the inter-State use of force serves in the first place to protect State sovereignty, but in doing so it also serves to protect individuals. Indeed, one might think of the ius ad bellum as an outer layer of protection of the right to life. The protection of State sovereignty and of territorial integrity - which in other ways often presents a barrier to the protection of human rights - can, in this sense, constitute an important component of the protection of individuals against lethal force, especially with the advent of armed drones, by containing the spread and intensity of armed conflicts. IHL and IHRL, by contrast, speak not to the inter-State use of force, but rather the specific features of a particular drone strike, such as how it is carried out, against whom it is carried out, and the consequences that follow. These differences notwithstanding, all three areas are closely related when discussing the use of lethal force across borders, and both international security and the protection of

\footnotetext{
${ }^{10}$ L Hill-Cawthorne, 'The Role of Necessity in International Humanitarian and Human Rights Law’ (2014) 47 IsraelLRev 225.
} 
the right to life depend on the principle that the use of force is a matter of last resort.

In order to examine the legality of a particular drone strike under international law, a holistic approach is therefore needed. For a particular drone strike to be lawful under international law, it must satisfy the legal requirements under all applicable international legal regimes. ${ }^{11}$ Although a particular drone strike may satisfy the requirements of the ius ad bellum, it may still be inconsistent with applicable rules of IHL and IHRL, and thus unlawful under international law. And the opposite may also be true: whereas a drone strike by a State may appear to comply with applicable rules of IHL and IHRL, if it does not satisfy the conditions for lawful force under the ius ad bellum, it will constitute an unlawful act under international law, entailing the responsibility of the State.

The importance of taking an holistic approach here is well illustrated by the example of an action by a State taken in self-defence. As discussed in more detail below, a valid claim to be acting in self-defence under Article 51 of the UN Charter, in response to an armed attack, may justify a use of armed force in another State's territory. However, a valid claim by a State to act in self-defence for the purposes of Article 51 is irrelevant to that State's compliance with those rules of IHL and IHRL that help to protect the right to life of those being targeted. Nor, as a matter of the secondary rules of State responsibility, can a valid claim to act in self-defence preclude the wrongfulness of conduct which otherwise violates applicable rules under IHL or IHRL. ${ }^{12}$ This position has been articulated clearly by the International Law Commission (ILC) in its commentary to the Articles on the Responsibility of States for Wrongful Acts. Although Article 21 of those Articles stipulates that lawful measures in self-defence will preclude the wrongfulness of an act, the ILC emphasized that:

This is not to say that self-defence precludes the wrongfulness of conduct in all cases or with respect to all obligations. Examples relate to international humanitarian law and human rights obligations ... As to obligations under international humanitarian law and in relation to non-derogable human rights provisions, self-defence does not preclude the wrongfulness of conduct. ${ }^{13}$

Similarly, while the consent of a State on whose territory force is used can justify what would otherwise be regarded as an infringement of territorial integrity by the State using force, such consent will not be relevant to the

11 KJ Heller, 'One Hell of a Killing Machine, Signature Strikes and International Law' (2013) 11 JICJ 89, 91; N Melzer, Targeted Killing in International Law (OUP 2009) 51-2.

${ }_{12}$ M Milanovic, Drones and Targeted Killing: Can Self-Defense Preclude their Wrongfulness? EJIL: Talk! (10 January 2010) available at <http://www.ejiltalk.org/drones-and-targeted-killingscan-self-defense-preclude-their-wrongfulness/ $>$.

${ }^{13}$ On the non-availability of self-defence as a circumstance precluding wrongfulness for breaches of IHL and IHRL, see International Law Commission (ILC), 'Commentary to art 21, Articles on Responsibility of States for Wrongful Acts' (2001) UNYBILC vol II, Pt Two; and J Crawford, The International Law Commission's Articles on State Responsibility: Introduction, Text and Commentaries (CUP 2002) 166. 
compliance of either State with any applicable rules of IHRL and IHL. The obligations of States under IHRL ${ }^{14}$ and $\mathrm{IHL}^{15}$ are not owed on a bilateral, reciprocal basis, but rather to each and every State party to the relevant treaty, and, for those treaty rules that co-exist under customary international law, to all States. In addition, IHRL and (some) IHL obligations are owed directly to individuals entitled to protection under these legal regimes. This nature of IHRL and IHL obligations means that one State cannot consent to another State violating the rights owed to individuals. ${ }^{16}$ Acts which violate these rights violate also the obligations owed to every other State party to the particular treaty (or to every other State in the case of obligations arising under customary international law) and the rights of individuals protected by the rules of IHRL. ${ }^{17}$

Each of the legal regimes explored in this article is therefore relevant to a different aspect of the use of drones, and each must be considered separately. In seeking to contribute towards greater clarity, and at least to take stock of the applicable legal framework as a whole, each of the three international legal regimes identified as relevant to the use of drones will be explored in turn.

\section{THE LAW RELATING TO THE USE OF FORCE ON FOREIGN TERRITORY}

We will begin by examining the law governing the inter-State use of force, the ius ad bellum, and its relevance for the employment of armed drones. The use by one State of drones to target individuals located in another State must in the first place comply with the rules on the inter-State use of force. While IHL and IHRL

14 Questions relating to the Obligation to Prosecute or Extradite (Belgium v Senegal) [2012] ICJ Rep 422, para 68.

15 The erga omnes nature of IHL can be seen in arts 1 of the 1949 Geneva Conventions and of Additional Protocol I of 1977 which impose on States an obligation not only to respect these treaties to but 'ensure respect' of the treaties. The 2016 ICRC Commentaries to art 1 of Geneva Conventions states that: 'The interests protected by the Conventions are of such fundamental importance to the human person that every High Contracting Party has a legal interest in their observance, wherever a conflict may take place and whoever its victims may be... . The Conventions thus create obligations erga omnes partes, i.e. obligations towards all of the other High Contracting Parties.' [para 119] The ICRC Commentary to art 1 of Additional Protocol I also states that: 'the [Diplomatic] Conference clearly demonstrated that humanitarian law creates for each State obligations towards the international community as a whole ("erga omnes"); in view of the importance of the rights concerned, each State can be considered to have a legal interest in the protection of such rights' (para 45). The ICRC Commentaries are available at < http://www.icrc.org/applic/ihl/ihl.nsf/ Comment.xsp?viewComments=LookUpCOMART\&articleUNID=6C86520D7EFAD527C125 63CD0051D63C $>$.

16 Similarly, the erga omnes nature of these obligations means countermeasures may not preclude wrongfulness for breaches of obligations under IHL and IHRL. See eg S Borelli and S Olleson, 'Obligations Relating to Human Rights and Humanitarian Law' in J Crawford, A Pellet and S Olleson (eds), The Law of International Responsibility (OUP 2010).

17 The ILC has made it clear that: 'In circumstances where the consent of a number of States is required, the consent of one State will not preclude wrongfulness in relation to another': ILC, 'Commentary to art 20, Articles on Responsibility of States for Wrongful Acts' (2001) UNYBILC vol II, Pt Two, paras 9 and 10. 
speak more directly to protection of the individuals affected by a drone strike, the law on the use of inter-State force focuses on State sovereignty; it serves primarily to protect the legal rights of States. This includes the right and interest of the State to have the lives of its citizens and inhabitants protected from acts of aggression. As was stated above, it can thus indirectly serve to protect life by containing the geographical spread of conflict.

Article 2(4) of the UN Charter and customary international law prohibit the threat or use of inter-State force. A State may, however, consent to the use of force on its territory by another State, with the result that Article 2(4) will not be engaged. Where no consent is given, the UN Charter gives two exceptions to the Article 2(4) prohibition: where action is taken lawfully in self-defence under Article 51 and where the Security Council authorizes enforcement action under Chapter VII of the UN Charter. Given that it is in these areas that many controversies especially arise, consent and self-defence will be considered in turn for their relevance to the use of drones by States abroad.

\section{A. Consent}

Where a territorial State consents to another State targeting non-State actors on the former's territory with drones, no issue in principle should arise under the ius ad bellum, for Article 2(4) of the UN Charter will not have been violated. ${ }^{18}$ Indeed, consent has been given by Pakistan, Yemen and Somalia which has then been relied upon by the U.S. to justify the use of drones in those territories; regarding Pakistan, this consent was subsequently withdrawn, whereas regarding Yemen and Somalia, though consent has not been withdrawn, the authority of those governments might call the validity of that consent into question. $^{19}$

While consent would seem a simple test that would result in a particular drone strike in foreign territory being consistent with the ius ad bellum, in practice there are issues of considerable difficulty surrounding consent, including who may give consent, whether consent must be given publicly and explicitly or

18 It has been suggested that a State cannot invite another State to assist it in a civil war, such that where the domestic situation is so severe, the de jure government would not be able to consent to force being used on its territory by another State: see C Gray, International Law and the Use of Force (OUP 2008) 81. However, this rule is supposedly derived not from the prohibition of the use of force but rather from the principle of non-intervention or perhaps the right of self-determination. In any event, it is not clear that there is sufficient State practice and opinio juris for such a limitation of the consent principle to be regarded as a part of international law: see Y Dinstein, War, Aggression and Self-Defence (CUP 2011) 119; D Akande and Z Vermeer, 'The Airstrikes against Islamic State in Iraq and the Alleged Prohibition on Military Assistance to Governments in Civil Wars' EJIL: Talk! (2 February 2015); and R Van Steenberghe, 'The Alleged Prohibition on Intervening in Civil Wars Is Still Alive after the Airstrikes against the Islamic State in Iraq: A Response to Dapo Akande and Zachary Vermeer' EJIL: Talk! (12 February 2015).

19 M Byrne, "Consent and the Use of Force: An Examination of "Intervention by Invitation" as a Basis for US Drone Strikes in Pakistan, Somalia and Yemen' (2016) 3 Journal on the Use of Force and International Law 97. 
could instead be implicit, and when consent could be considered to have been vitiated by coercion. ${ }^{20}$

With regard to who may give consent, the fundamental nature of the prohibition of the use of force for State sovereignty means that only the State's highest authorities may validly give consent - that is, have the authority to give consent - to a use of force. ${ }^{21}$ One cannot simply rely on the notion of attribution under the secondary rules on State responsibility by analogy. Although the acts of all government officials, acting in that capacity, are attributable to the government, not all parts of the government are entitled to give consent with respect to the use of force. In particular, it is not sufficient to obtain consent from regional authorities or from particular agencies or departments of government. The International Law Commission has made it clear that:

[w] hether a particular person or entity had the authority to grant consent in a given case is a separate question from whether the conduct of that person or entity was attributable to the State ... For example, the issue has arisen whether consent expressed by a regional authority could legitimize the sending of foreign troops into the territory of a State, or whether such consent could only be given by the central Government, and such questions are not resolved by saying that the acts of the regional authority are attributable to the State $\ldots . .^{22}$

The answer to the question of which domestic authority is entitled to give consent to what would otherwise constitute a violation of international law depends on the interplay between international and domestic law. In the first place, one needs to consider the nature of the international rule in question and the manner in which that rule is generally applied. ${ }^{23}$ As already stated, the importance of the prohibition on the use of force suggests that consent to a departure from this rule will usually need to be established at the highest levels of government. Secondly, one will need to consider the domestic arrangements made with respect to the matter at hand. ${ }^{24}$ Where domestic law

20 The controversies surrounding the issue of consent more generally are discussed in $\mathrm{J}$ Crawford, The International Law Commission's Articles on State Responsibility: Introduction, Text and Commentaries (CUP 2002) 163-5.

21 See O Corten, The Law Against War: The Prohibition on the Use of Force in Contemporary International Law (Hart 2010) 259: 'In the case of a military operation, no one contests that only the highest authorities of the State are able to issue such consent validly. It is only on this condition that it can be claimed that a use of force is not directed against the State's independence and so does not violate article 2(4),'

${ }^{22}$ See ILC, 'Commentary to art 20, Articles on Responsibility of States for Wrongful Acts' (2001) UNYBILC vol II, Pt Two, para 5.

23 The ILC has stated that: 'Who has authority to consent to a departure from a particular rule may depend on the rule. It is one thing to consent to a search of embassy premises, another to the establishment of a military base on the territory of a State. Different officials or agencies may have authority in different contexts, in accordance with the arrangements made by each State and general principles of actual and ostensible authority': ibid, para 6 .

24 It has also been argued that where a State's actions on another's State's territory are consented to by the latter, the former should inquire into whether this consent complies with the latter's 
or domestic constitutional arrangements are such as to give responsibility on these issues to lower level officials this may be taken into account.

However, it would be natural that where there is a difference of view between the highest authorities in government and lower-level officials, it is the view of the higher-level officials that should be taken as determinative. This arises in part because international law itself assumes that certain organs of government have the capacity to represent the State in international affairs. Thus, the Head of State, Head of Government and the Foreign Minister are presumed, as a matter of international law, to have plenary competence to conclude treaties on behalf of the State. ${ }^{25}$ In addition, these senior government officials are accorded immunity ratione personae from the jurisdiction of other States because of their privileged position in conducting international relations on behalf of the State. ${ }^{26}$ Thus, it can be assumed that it is the view of these officials, where expressed, that should be determinative of whether the State gives consent or not to the use of force on the State's territory. Importantly, the view that consent to the use of force must be given by the highest authorities in the central government of a State accords with the bulk of international practice. ${ }^{27}$

Regarding the issue of publicity and consent, while there does not appear to be a requirement that consent be made public, it must nevertheless be clear as between the States concerned that consent is being given to the use of force, and the parameters of that consent should also be made clear. Consent must be given in advance. ${ }^{28}$ Moreover:

... certain modalities need to be observed for consent to be considered valid. Consent must be freely given and clearly established. It must be actually expressed by the State rather than merely presumed on the basis that the State would have consented if it had been asked. Consent may be vitiated by error, fraud, corruption or coercion. In this respect, the principles concerning the validity of consent to treaties provide relevant guidance. ${ }^{29}$

Consent on so serious a matter as the use of force is not to be implied. Furthermore, where force exceeds the limits of the consent given, that force

domestic law: A Deeks, 'Consent to the Use of Force and International Law Supremacy' (2013) 54 HarvIntlLJ 1.

25 Art 7 of the 1969 Vienna Convention on the Law of Treaties.

26 Arrest Warrant of 11 April 2000 (DRC v Belgium) [2002] ICJ Rep 3, paras 53-55; D Akande and S Shah, 'Immunities of State Officials, International Crimes and Foreign Domestic Courts (2010) 21 EJIL 815, 818ff.

27 Corten (n 21) 266: 'In respect of all the precedents just examined, it appears clearly that, to be validly given, consent to external intervention must have been given by the highest authorities of the State such as the Prime Minister, the President or the Government as a whole.'

28 'Consent to the commission of otherwise wrongful conduct may be given by a State in advance or even at the time it is occurring. By contrast, cases of consent given after the conduct has occurred are a form of waiver or acquiescence, leading to loss of the right to invoke responsibility': ILC, 'Commentary to art 20, Articles on Responsibility of States for Wrongful Acts’ (2001) UNYBILC vol II, Pt Two.

29 See ibid, para 6. 
will be a violation of Article 2(4). ${ }^{30}$ In addition, once consent to the use of force is withdrawn, the State conducting targeting operations is bound by international law to refrain from conducting any further operations from that moment onwards (unless there is a separate justification for using force). ${ }^{31}$

\section{B. Self-Defence}

Where no consent is given, Article 2(4) will be engaged by a drone strike on another State's territory, requiring resort to one of two exceptions to the prohibition contained in the UN Charter. The most common exception invoked by States using drones in these situations is self-defence. ${ }^{32}$ International law poses stringent conditions on the use of force in selfdefence. Under Article 51 of the UN Charter and customary international law, a State may invoke self-defence to justify its use of force to target individuals on another State's territory where an armed attack against it occurs or is imminent (on which see below). The International Court of Justice (ICJ) has confirmed that, for an attack to constitute an 'armed attack' and thus enable the State's right to use force in self-defence, the scale and effects of the attack must reach a certain threshold of gravity. ${ }^{33}$ Thus, not any use of force against a State will necessarily justify a response in self-defence; rather, only grave uses of force can do so.

In addition to the requirement of an armed attack, the State claiming to be acting in self-defence must also satisfy the dual requirements of necessity and proportionality, grounded in customary international law. ${ }^{34}$ These requirements, as defined in the context of the ius ad bellum, are closely linked to the important issue of the aim of an act of self-defence. Thus, 'necessity and proportionality mean that self-defence must not be retaliatory or punitive; the aim should be to halt and repel an attack'. ${ }^{35}$ In other words,

${ }^{30}$ ibid, para 9: 'where consent is relied on ... it will be necessary to show that the conduct fell within the limits of the consent'.

${ }^{31}$ See Case Concerning Armed Activities on the Territory of the Congo (Democratic Republic of the Congo v Uganda) [2005] ICJ Rep 168, para 105, where the ICJ took the view that Ugandan presence in the DRC was unlawful from the moment when consent was withdrawn (despite an agreement setting out modalities for withdrawal).

${ }^{32}$ The US and UK, for example, rely on self-defence: US Department of Justice White Paper, 'Lawfulness of a Lethal Operation Directed Against a U.S. Citizen Who is a Senior Operational Leader of Al-Qa'ida or an Associated Force' (made public 5 February 2013); E MacAskill, 'Drone killing of British citizens in Syria marks major departure for UK', The Guardian, 7 September 2015.

${ }^{33}$ Case Concerning Military and Paramilitary Activities In and Against Nicaragua (Nicaragua $v$ United States) [1986] ICJ Rep 14, para 191; Case Concerning Oil Platforms (Iran v United States) [2003] ICJ Rep 161, paras 51, 62.

34 The ICJ has on numerous occasions highlighted the need for a response to an armed attack to be necessary and proportionate for that to constitute lawful self-defence: see Nicaragua (n 33) para 194; Legality of the Threat or Use of Nuclear Weapons, Advisory Opinion [1996] IC Rep 226, para 41; Oil Platforms (n 33) para 74; DRC v Uganda (n 31) para 147.

${ }_{35}$ Gray (n 18) 150; see also A Randelzhofer, 'Article 51' in B Simma et al. (eds), The Charter of the United Nations: A Commentary (3rd edn, OUP 2012); D Akande and T Liefländer, 
action taken lawfully in self-defence (eg the use of drones to target individuals in another State's territory) must serve the purpose of halting and repelling an armed attack and must be both necessary and proportionate to this end. ${ }^{36}$ Action taken after an armed attack has ended, and which in reality seeks to retaliate against that armed attack, would not constitute a lawful exercise of selfdefence, but rather an armed reprisal in violation of Article 2(4) of the UN Charter. ${ }^{37}$ In considering the elements relevant to determining whether a particular action is necessary and proportionate to the aim of self-defence, the ICJ in the Oil Platforms case placed emphasis on the nature of the objects targeted by the US and their role in staging any initial armed attacks. ${ }^{38}$

The requirements of necessity and proportionality also help to define the limits of the right to self-defence. The right persists only for so long as it is necessary to halt or repel an armed attack and must be proportionate to that aim. However, that is not to say that, in determining what is necessary to bring an attack to an end and what is a legitimate objective for self-defence, States are entitled to continue to act in self-defence until the absolute destruction of the enemy is achieved such that the enemy poses no long-term threats. International law cannot permit States to act until the elimination of long-term threats is secured. The law of self-defence permits responses to emergency situations in which States face immediate or imminent risks. Once the immediate or imminent threats of (continued) attack are resolved, States will need to find other methods of securing long-term peace and stability.

To permit force to be used as a means of achieving long-term security where the threat of immediate or imminent attacks has receded, is to permit perpetual warfare. Therefore, even when drones are used in self-defence, consideration needs to be given to the moment when the group against which drones are being used is sufficiently disrupted such that it no longer poses an immediate or imminent threat.

The question of 'imminence' raises a further controversial point of considerable importance to the use of armed drones abroad. Article 51 recognizes the right to self-defence where 'an armed attack occurs', but also refers to self-defence as an 'inherent' right of States. This has given rise to arguments that the right to self-defence under customary law is not displaced

'Clarifying Necessity, Imminence, and Proportionality in the Law of Self-Defense' (2013) 107 AJIL 563,569 .

36 The manner in which the requirements of necessity and proportionality have been invoked by the ICJ confirms this interpretation of the purpose of lawful self-defence: see eg Nicaragua (n 33) para 237 (holding that US actions in and against Nicaragua were not necessary as the threat to the Salvadorian government had already been curbed by other means); Oil Platforms (n 33) para 76 (holding that the US attacks against Iranian oil platforms were not necessary to respond to the attacks against US ships); see also Legality of the Threat or Use of Nuclear Weapons (n 34), Dissenting Opinion of Judge Higgins, para 5 ("the concept of proportionality referred to was that which was proportionate to repelling the attack, and not a requirement of symmetry between the mode of the initial attack and the mode of response').

37 Oil Platforms (n 33), Dissenting Opinion of Judge Elaraby, para 1.2.

38 Oil Platforms (n 33). 
by the Charter. Importantly, the argument that an anticipatory attack against an imminent threat is permissible rests on this basis. ${ }^{39}$ There is a significant debate about the legality of action in self-defence prior to an actual armed attack. However, as the Report of the High-Level Panel Established by the UN Secretary-General noted: 'Long-established customary international law makes it clear that States can take military action as long as the threatened attack is imminent, no other means would deflect it, and the action is proportionate.' 40 The UK, for example, takes the view that action in selfdefence can be lawful where an armed attack is imminent. ${ }^{41}$

Importantly, at most anticipatory self-defence could be lawful only in response to an existing threat. It may not be employed pre-emptively to prevent a threat from arising in the future. The necessity of self-defence, according to the well-known construction, 'must be instant, overwhelming, and leaving no choice of means, no moment of deliberation'. ${ }^{42}$ The body of opinion and State practice that rejects the concept of anticipatory self-defence altogether should also be noted, and serves at least as a confirmation of the limited scope of the exception. ${ }^{43}$

Finally, it must be emphasized that the imminence requirement in IHRL which stipulates that intentional lethal force may be used only to protect life, is not to be conflated with the requirement of imminence in the law governing the use of force on foreign territory under Article 51. The former is a condition required for all uses of lethal force to be lawful under IHRL. The latter applies under the doctrine of anticipatory self-defence and the legality of a use of force on another State's territory under the ius ad bellum. ${ }^{44}$ Meeting the requirement of imminence under one regime may not necessarily satisfy the test under the other. This is consistent with one of the key themes of the present article, that separate assessments of the legality of drone strikes under each applicable branch of international law must be undertaken.

A further controversy that must also be considered here concerns self-defence measures taken in a foreign State against non-State actors who do not act on behalf of that foreign State. This question is of particular importance given that non-State actors are currently being targeted by drones in States that do not necessarily bear responsibility for the acts of those actors. ${ }^{45}$ Prior to $9 / 11$, the claim that force could be used in self-defence in response to an armed attack

\footnotetext{
39 Report of the High-Level Panel Established by the UN Secretary-General (December 2004) UN Doc A/59/565 (2004) at 188-92. $\quad 40$ ibid.

41 'Attorney-General's Advice on the Iraq War, Iraq: Resolution 1441' (2005) 54 ICLQ 767, 768.

42 Letter from Mr. Webster to Lord Ashburton, August 6, 1842 in RY Jennings, 'Caroline and McLeod Cases' (1938) 32 AJIL 82.

43 Gray (n 18) 160-1.

${ }^{44}$ Contrast the US Department of Justice White Paper, 'Lawfulness of a Lethal Operation Directed Against a U.S. Citizen Who is a Senior Operational Leader of Al-Qa'ida or an Associated Force' (5 February 2013).

45 See references above at nn 3-6 for news articles detailing drone strikes by the UK and US against non-State actors in a number of different countries.
} 
by a non-State group whose acts were not attributable to a State was controversial at best. ${ }^{46}$ The International Court of Justice rejected this view of the law in the Nicaragua case. ${ }^{47}$

However, State practice since the events of 11 September 2001 suggests that international law now permits such a notion of self-defence. The shift began with the near universal support for the US and UK's response in Afghanistan to the 9/ 11 attacks, which was based on a claim to be acting in self-defence against a nonState group operating from a State where the actions of that group could not be said to be attributable to the territorial State using ordinary rules of attribution under the law of state responsibility. ${ }^{48}$ Indeed, following the events of $9 / 11$, the Security Council adopted Resolutions 1368 and 1373, both of which recognized 'the inherent right of individual or collective self-defence in accordance with the Charter' ${ }^{49}$ This would suggest that a State may use force in self-defence on another State's territory, where that first State has been the victim of an armed attack by non-State groups operating on the latter's territory, even where that attack is not attributable to the 'host' State.

In contrast, the ICJ in its Israeli Wall advisory opinion subsequently implied that inter-State force cannot be used in self-defence in response to an armed attack by a non-State actor:

Article 51 of the Charter thus recognizes the existence of an inherent right of selfdefence in the case of armed attack by one State against another State. However, Israel does not claim that the attacks against it are imputable to a foreign State. ${ }^{50}$

Nonetheless, State practice relating to the use of force abroad against non-State actors, since 2001, is now broad and extensive, and indeed it extends beyond the immediate post-9/11 context. ${ }^{51}$ Following this practice, and despite academic controversy, ${ }^{52}$ the law on this matter, appears to have changed.

${ }^{46}$ See discussion of pre-9/11 practice in Gray (n 18) 195-8. ${ }^{47}$ Nicaragua (n 33) para 195.

48 See eg the US' letter to the Security Council under art of the UN Charter, in which it referred to its right to self-defence against al-Qaida and the Taliban regime in Afghanistan that was allowing its territory to be used by al-Qaida: UN Doc S/2001/946. The same claim was made by the UK: UN Doc S/2001/947.

49 UN Security Council Resolution 1368 (12 September 2001) S/RES/1368 (2001), preambular para 3; Security Council Resolution 1373 (28 September 2001) S/RES/1373 (2001), preambular para 4.

${ }^{50}$ Legal Consequences of the Construction of a Wall in the Occupied Palestinian Territory, Advisory Opinion [2004] ICJ Rep 136, para 139. It is to be noted that art 51 does not, in fact, condition the notion of armed attack as emanating from a State only.

${ }^{51}$ For example, since 9/11 one may refer to Uganda and Rwanda's use of force in the DRC; Kenya and Ethiopia's use of force in Somalia; Russia's use of force in Georgia; Israel's use of force against Hezbollah in Lebanon; Turkey's repeated use of force in northern Iraq; Saudi Arabia's use of force in Yemen; Colombia's use of force in Ecuador; the use of force by many States in Syria against ISIS. As Christian Tams notes, "[t]he situations in which force has been used (or a corresponding right has been asserted) vary considerably, but have almost exclusively been explained as exercises in self-defence': C Tams, 'The Use of Force against Terrorists' (2009) 20 EJIL 359, 378.

52 See generally, Tams ibid 359; A Deeks, “'Unwilling or Unable”: Toward a Normative Framework for Extraterritorial Self-Defense' (2012) 52 VaJIntlL 483 and M Hakimi, 'Defensive 
However, even if States may, in certain circumstances, lawfully exercise selfdefence in response to an armed attack against a non-State actor, this only means that the armed attack requirement can be fulfilled without attribution of the attack to a State. Other customary international law requirements would still need to be fulfilled before a State can respond with force in self-defence on the territory of another State. In particular, it must be necessary and proportionate to respond with force to an armed attack (or imminent armed attack) from a non-State actor. In the context of a use of force against a nonState group, it is suggested that the necessity condition would only be satisfied where the territorial State itself is either unable or unwilling to prevent continued attacks. ${ }^{53}$ It is worth emphasizing that this test of whether the territorial State is unable or unwilling to act is not an independent legal standard but merely an aspect of the application of the long-standing criterion of necessity. In determining whether a State is unable or unwilling to take action, the State acting in self-defence might be required to request permission for such action prior to the commencement of acts taken in self-defence. ${ }^{54}$

Finally, Article 51 of the UN Charter makes it clear that measures adopted by States in exercise of self-defence must be reported to the UN Security Council. ${ }^{55}$ This can be seen as posing an obligation of transparency and justification to the international community, placing the issue formally on the agenda of the Security Council and recognizing its role. All member States of the UN have an obligation under its founding treaty to submit such reports. While failure to report will not render unlawful an otherwise lawful action taken in selfdefence, 'the absence of a report may be one of the factors indicating whether the State in question was itself convinced that it was acting in self-defence'. ${ }^{56}$ According to Article 51 the right to exercise self-defence shall continue 'until the Security Council has taken measures necessary to maintain international peace and security'. This demonstrates that the end point of an action in selfdefence is not only determined by the principles of necessity and proportionality, noted above, but may also be determined by the Security Council. ${ }^{57}$

In addition to its transparency function, it could be argued that the rationale for this reporting requirement is to contribute towards the protection of the legal rights of sovereignty by the international community, since the State using force is required to offer its justification for that use of force. By extension, it must be concluded that a State must report afresh when the material facts have changed-for example, where self-defence is used as a basis for the use of

Force against Non-State Actors: The State of Play' (2015) 91 International Law Studies 1; N Lubell, Extraterritorial Use of Force Against Non-State Actors (2010 OUP) Pt I.

53 K Trapp, 'Back to Basics: Necessity, Proportionality, and the Right of Self-Defence against Non-State Terrorist Actors' (2007) 56 ICLQ 141; D Bethlehem, 'Self-Defense Against an Imminent or Actual Armed Attack by NonState Actors' (2012) 106 AJIL 770, 776.

${ }_{55}$ Nicaragua (n 33) para 235; DRC v Uganda (n 31) 222, para 145.

57 Randelzhofer (n 35) 804. 
force on the territory of a new State, or where new parties are added to the conflict.

\section{INTERNATIONAL HUMANITARIAN LAW}

Having considered a number of the varied issues that arise in applying the rules under the ius ad bellum to the use of armed drones by States, this section will now explore the second key body of international law of relevance here, that is, international humanitarian law (IHL). IHL applies only where there is a situation of either international or non-international armed conflict. As such, whether a particular drone strike is regulated by IHL will depend on whether that strike falls within the context of one of these types of armed conflict. If a drone strike does not take place in the context of an armed conflict, IHL will not apply, and the applicable rules of IHRL will continue exclusively to govern the use of lethal force. The test whether an armed conflict exists is an objective, factual one and is not determined by the subjective views as to the characterization of the situation by the parties involved. This section will consider some of the key controversies in the application of IHL to drone strikes.

\section{A. The Threshold for Non-International Armed Conflict}

Where a State targets non-State actors abroad, that act may, depending on the fulfilment of other conditions, take place in the context of a non-international armed conflict, ${ }^{58}$ and thus be governed by the rules of IHL applicable in that type of conflict. Classification of situations as international or noninternational armed conflicts depends primarily on the question of who are the parties to the conflict. Conflict between States, are, according to Common Article 2 of the 1949 Geneva Conventions, international armed conflicts. Violence between a State and an organized non-State armed group, or between two or more such groups, may be a non-international armed conflict. It is generally accepted that a non-international armed conflict may take place across State boundaries, with the phrase 'non-international' referring not to the territorial scope of the conflict but to the status of the parties. ${ }^{59}$

Drones have thus far typically not been used in inter-State conflict. The question thus arises whether they are being used in non-international armed

\footnotetext{
58 Unless the non-State group acts on behalf of a foreign State, in which the conflict would be international.

59 Thus, the wording of Common Article 3 to 1949 Geneva Conventions which speaks of a noninternational armed conflict in the territory of one of the parties is regarded as requiring only the fighting takes place at least on the territory of one party to the Geneva Conventions. On this, see Hamdan $v$ Rumsfeld, 542 US 507 (2004); N Lubell, 'The War (?) Against Al-Qaeda' in E Wilmshurst (ed), International Law and the Classification of Conflicts (OUP 2012) 432-3; D Akande, 'Classification of Armed Conflicts: Relevant Legal Concepts', in Wilmshurst, ibid, 72.
} 
conflicts (NIACs). For violence to amount to a non-international armed conflict there must be 'protracted armed violence between governmental authorities and organized armed groups or between such groups within a State'. ${ }^{60}$ Two cumulative criteria must thus be satisfied in order for a particular situation to be classified as a non-international armed conflict to which IHL would apply. These two criteria relate to: "the intensity of the conflict and the organisation of the parties to the conflict' ${ }^{61}$ Thus, an armed group will only be considered to constitute a party to a NIAC if it is sufficiently organized. International jurisprudence has determined the relevant indicative criteria, which include, inter alia, the existence of a command structure, headquarters, and a group's ability to plan and carry out military operations. ${ }^{62}$

Moreover, for a conflict to qualify as a NIAC, armed violence must also reach a certain threshold of intensity which is higher than that of internal disturbances and tensions. ${ }^{63}$ The armed violence should not be sporadic or isolated but protracted. ${ }^{64}$ The requirement of protracted violence 'refers more to the intensity of the armed violence than its duration' ${ }^{65}$ Like the condition of organization, the intensity of the armed violence is an issue which is determined on a case-by-case basis. ${ }^{66}$

In the context of drones, these requirements mean that IHL will not apply where the threshold levels of violence or organization are not present, leaving IHRL to govern the situation alone. It should be noted that individual drone strikes by themselves are not likely to meet the necessary threshold of violence for a NIAC to come into existence, leaving IHL inapplicable unless a drone strike is used in the context of a pre-existing NIAC.

A number of controversies have, however, arisen with regard to the scope of non-international armed conflicts and the threshold criteria for their existence, as a result of claims made by particular States when employing armed drones abroad. For example, where a State employs armed drones against members of the same non-State group in a number of different territories, the question arises as to whether the violence between the State and non-State group should be treated as a single, global non-international armed conflict. ${ }^{67}$ The consequence of following such an approach would be that, when assessing

60 Prosecutor v Tadić (Decision on the Defence Motion for Interlocutory Appeal on Jurisdiction) ICTY-94-1 (2 October 1995) para 70.

61 Prosecutor v Tadić (Trial Judgment) IT-94-1-T (7 May 1997) para 562.

62 Prosecutor v Limaj and others, Case No IT-03-66-A, 30 November 2005, paras 94-134; Prosecutor v Lubanga, No ICC-01/04-01/06-2842, 14 March 2012, paras 536-538.

${ }^{63}$ Art 1(2) of Additional Protocol II of 1977; Prosecutor v Musema (Appeals Judgment) ICTR96-13-A (16 November 2001) para 248.

64 Musema, ibid.

65 Prosecutor $v$ Haradinaj and others Judgment (Trial Chamber) IT-04-84-T ICTY (3 April 2008) para 49; Prosecutor v Limaj et al. (n 62) para 90. ${ }_{66}^{6}$ Musema (n 63) para 249.

67 See eg the ICRC's criticisms of the view that the international fight against terrorism constitutes a single, transnational non-international armed conflict: ICRC, 'International Humanitarian Law and Terrorism: Questions and Answers', 1 January 2011, available at <http:// www.icrc.org/eng/resources/documents/faq/terrorism-faq-050504.htm\#Dosomeaspectsofthefight againstterrorismamounttoatransnationalarmedconflict $>$. 
whether the intensity threshold for a non-international armed conflict had been met, one would aggregate the entirety of the violence between the State and nonState group across the globe. It might be argued that where a State targets in different States, members of the same (sufficiently organized) non-State armed group, with which it is already in a non-international armed conflict, a single, global non-international armed conflict exists, with the relevant rules of IHL applying to all such strikes. ${ }^{68}$ If this approach is followed, the intensity requirement could be met by aggregation of violence, rather than by examining the level of violence in each country. The result of such an approach is that, on some views, the less protective rules of IHL will apply in such cases to those targeted and exclude or modify the more protective rules of IHRL. Under this model, unsuspecting communities, far away from any battlefield, may lawfully be significantly affected so long as they are not disproportionately so (on proportionality, see below).

This result does, of course, depend on one's view of the interaction between IHL and IHRL in this area. If the ICJ's approach to the interaction between IHL and the right to life under the International Covenant on Civil and Political Rights (ICCPR) is applied equally in non-international armed conflicts, ${ }^{69}$ then the right to life of the person targeted would not be violated so long as IHL is complied with.

The possibility of a non-international armed conflict which spans across more than one country could certainly only exist where the individuals against which the State uses force in those several countries are actually members of the same non-State group. ${ }^{70}$ This is because the violence can only be part of the same armed conflict if it is between the same parties. Where violence is between entities that are not parties to the same conflict, that violence cannot be part of a single non-international armed conflict. Thus, in a supposed global noninternational armed conflict, the fulfilment of the organized armed group criterion would have to be tested on a global basis. ${ }^{71}$ Where there is no single organization that groups together all those fighting then the test for an

68 See eg N Lubell and N Derejko, 'A Global Battlefield? Drones and the Geographical Scope of Armed Conflict' (2013) 11 JICJ 65. Amongst the many pieces written on this issue from the perspective of drone strikes, see eg L Blank, 'Defining the Battlefield in Contemporary Conflict and Counter-Terrorism: Understanding the Parameters of the Zone of Combat' (2010) 39 GaJIntl\&CompL 1; K Anderson, 'Targeted Killing and Drone Warfare: How We Came to Debate Whether There Is a "Legal Geography of War"” (2011) Washington College of Law Research Paper No 2011-12; J Daskal, 'The Geography of the Battlefield: A Framework for Detention and Targeting Outside the "Hot" Conflict Zone' (2013) 161 UPaLRev 1165.

69 See Legality of the Threat or Use of Nuclear Weapons (n 34) para 25.

70 See Lubell and Derejko (n 68) 78 stating that where the individuals targeted by drone strikes are not members of the same non-State armed groups with which the targeting State is already in an armed conflict, 'it will become necessary to show that a separate armed conflict exists between the state and the targeted armed group').

71 Lubell and Derejko (n 68) ('It is, however, highly questionable as to whether a one-sided drone strike can meet the threshold of intensity for armed conflict ... It is therefore submitted here that drone strikes alone are unlikely to be sufficient for the determination of a NIAC and the ensuing applicability of IHL.'). 
organization would not be met, and one could not aggregate all the violence together for the purposes of the intensity criterion.

There is clearly an incentive for States that are engaged in military clashes to define the group with whom they are engaged so broadly as to capture those not really members thereof, so as to bring them all within the same non-international armed conflict. The way in which the existing organization criterion under IHL has been interpreted to some extent helps to protect against this. An armed group is a party to a non-international armed conflict if, and only if, it is sufficiently organized in accordance with the demands of IHL. An armed group will only be sufficiently organized to be a party to a non-international armed conflict, if there is 'a sufficient body of evidence pointing to the ... [group] being an organized military force, with an official joint command structure, [and] headquarters ...' ${ }^{72}$ Moreover the group should have 'a unified military strategy' and be 'able to speak with one voice'. ${ }^{73}$ Importantly, this is a factual, objective test, immune from the political considerations of the attacking State; it is not, therefore, for the State party to a NIAC to define for itself what constitutes the armed group against which it is fighting.

A related controversy arising from the use by certain States of drones against non-State armed groups abroad involves claims by certain States that force may be used not only against an organized armed group in a situation that meets the above requirements but also against its co-belligerents (or 'affiliates' or 'associates'). ${ }^{74}$ Co-belligerency is a concept that applies in international armed conflicts and entails that a sovereign State becomes a party to a conflict either through formal or informal processes. ${ }^{75}$ A treaty of alliance may be concluded as a formal process, while the informal process could involve providing assistance to or establishing a 'common cause' with belligerent forces. ${ }^{76}$

Transposing the concept of co-belligerency into non-international armed conflicts has been met with resistance because it ignores the significant differences between the two types of armed conflict and opens the door for an expansion of targeting without clear limits. ${ }^{77}$ Where the individuals targeted are not part of the same command and control structures as the organized armed group or are not part of a single military hierarchical structure, they ought not to be regarded as part of the same group, even if there are close ties between the

\footnotetext{
72 Prosecutor v Milosevic (Decision on Motion for Judgment of Acquittal) IT-02-54-T (16 June 2004), para 23

73 Haradinaj (n 69) para 60.

$74<$ http://www.whitehouse.gov/the-press-office/2013/02/12/remarks-president-state-unionaddress $>$; C Bradley and J Goldsmith, 'Congressional authorization and the war on terrorism' (2005) 118 HarvLRev 2112, 2113.

${ }_{75}$ H Lauterpacht (ed), Oppenheim, International Law: A treatise (1935) 203, 206. 76 ibid.

77 'The [U.S.] administration's failure to define what specific organizational features or conduct would lead a group to be classified as an associated force raises concerns that this results in an aggressive and indefinitely expansive scope of targeting authority': Amnesty International, 'Statement of Shared Concerns Regarding U.S. Drone Strikes and Targeted Killings', AI Index: AMR 51/017/2013, 6 .
} 
different groups. ${ }^{78}$ As a result, one cannot aggregate the violence between the State and these different armed groups as part of the determination as to whether the threshold for non-international armed conflicts has been met. Violence by different organized armed groups against the same State can amount to noninternational armed conflicts only where the intensity of violence between each group and the State individually crosses the intensity threshold.

To illustrate the points made above, one may make reference to the possibility of a single, global non-international armed conflict with al-Qaeda, for which it was stated that ' $[\mathrm{t}]$ here is little evidence that the various terrorist groups that call themselves AQ or associate themselves with AQ possess the kind of integrated command structure that would justify considering them a single party involved in a global NIAC with the US ... Indeed, even the US government rejects the idea that AQ is a unified organization, dividing AQ into three separate tiers.' 79 The view of the International Committee of the Red Cross (ICRC) was that, based on the facts, this type of NIAC was not and has not been taking place. Instead, a case-by-case approach to legally analysing and classifying the various situations of violence that have occurred in the fight against terrorism should be applied. Seen in this light, some of these situations may be classified as an international armed conflict, others as NIACs, while the rest may be outside any armed conflict. ${ }^{80}$

A final, important point must be emphasized here, in keeping with the general theme of this article that each applicable legal regime must be addressed separately to determine the legality of a particular drone strike under international law. Even if the concept of a global non-international armed conflict is accepted, IHL does not, on its own, determine whether armed force can be used in foreign States. IHL simply governs how force may be used and does not regulate whether or when armed force may be used. It is the ius ad bellum which determines whether force may be used on foreign territory and which restrains the extraterritorial use of force. Thus, accepting the possibility of a global non-international armed conflict between a State and a non-State group does not in itself give permission to States to use force on foreign territory. Whether a State can carry the fight to a(nother) foreign territory will depend on the law relating to the use of force. The State seeking to carry out a drone attack in a particular foreign State will need to show that there is a sufficient, and indeed, separate justification under the law relating to the use of force for any attacks on each individual foreign State territory. In particular, the necessity of using force in self-defence on the territory of that particular State will need to be assessed separately.

\footnotetext{
78 For what constitutes an armed group, see Haradinaj (n 65) paras 144-145.

79 Heller (n 11).

80 ICRC, 'International Humanitarian Law and the challenges of contemporary armed conflicts' (2011) $10 \mathrm{ff}$.
} 


\section{B. Who May Be Targeted under the Law of Non-International Armed Conflict?}

Once it has been established that a non-international armed conflict exists, and thus that the rules of IHL applicable in such situations apply in the specific case, the next question concerns who may be targeted. The law of non-international armed conflict is less settled in this area than the law of international armed conflict. It is clear that, as a matter of both treaty and customary law, civilians may not be made the object of an attack unless, and for such time as, they take a direct part in hostilities (DPH) ${ }^{81}$ This is the principle of distinction and constitutes one of the cardinal principles of targeting under IHL. Where there is doubt as to whether a person is a civilian or is taking a direct part in hostilities, civilian status must be presumed. ${ }^{82}$

The treaty rules applicable in non-international armed conflict, however, do not define 'civilian', and there have been debates about whether members of non-State armed groups may be targeted on the basis of their status alone (eg as combatants can in international armed conflicts). In its Interpretive Guidance on Direct Participation in Hostilities, the ICRC has taken the view that 'civilians' protected from direct attack in a NIAC are all those who are neither members of a State's armed forces nor members of organized armed groups. The latter are then defined as 'individuals whose continuous function it is to take a direct part in hostilities ("continuous combat function" or CCF) ${ }^{83}$ They may be targeted based on their status alone.

Thus, where a drone strike is carried out against an individual with a continuous combat function in an organized armed group with which the attacking State is engaged in a NIAC, this will be consistent with the principle of distinction in IHL, though of course the other applicable rules of IHL also must be observed. However, 'recruiters, trainers, financiers and propagandists may continuously contribute to the general war effort of a nonState party, but they are not members of an organized armed group belonging to that party unless their function additionally includes activities amounting to direct participation in hostilities. ${ }^{\circ 4}$ Such persons, therefore, remain civilians, protected against attack unless they directly participate in hostilities.

In addition to targeting on the basis of status, individuals may be targeted as result of conduct they have undertaken. Civilians lose their protection from direct attack where, and for such time as, they take a direct part in hostilities.

${ }^{81}$ Art 13(2) and (3) of Additional Protocol II of 1977. See also J-M Henckaerts and L DoswaldBeck, Customary International Humanitarian Law Volume I: Rules (CUP 2005) Rule 6.

${ }^{82}$ Art 13(2) and (3) of Additional Protocol II of 1977; art 50(1) of Additional Protocol I of 1977.

${ }^{83}$ ICRC (Melzer), Interpretive Guidance on the Notion of Direct Participation in Hostilities under International Humanitarian Law (ICRC 2009) 27. See also S Sivakumaran, The Law of Non-International Armed Conflict (OUP 2012) 359-62. Others adopt a different approach to defining membership of organized armed groups; see eg Y Dinstein et al., The Manual on the Law of Non-International Armed Conflict: With Commentary (International Institute of Humanitarian Law 2006); K Watkin, 'Opportunity Lost: Organized Armed Groups and the ICRC 'Direct Participation in Hostilities' Interpretive Guidance' (2010) 42 NYUJIntIL\&Pol 641.

${ }^{84}$ ICRC, Interpretive Guidance, ibid 34. 
According to the ICRC there is a three-stage (cumulative) test for determining when a civilian is directly participating in hostilities and thus may be targeted..$^{85}$ In order for activity to qualify as direct participation in hostilities:

1. The act must be likely to adversely affect the military operations or military capacity of a party to an armed conflict or, alternatively, to inflict death, injury, or destruction on persons or objects protected against direct attack (threshold of harm); 2. There must be a direct causal link between the act and the harm likely to result either from that act, or from a coordinated military operation of which that act constitutes an integral part (direct causation); and 3. The act must be specifically designed to directly cause the required threshold of harm in support of a party to the conflict and to the detriment of another (belligerent nexus). ${ }^{86}$

The most important criterion with respect to direct participation in hostilities is the requirement that the civilian either carries out acts that directly cause harm or engages in an operation that directly causes harm. ${ }^{87}$ The ICRC has defined this requirement narrowly, stating that 'direct causation should be understood as meaning that the harm in question must be brought about in one causal step'. ${ }^{88}$ General production and transport of weapons, or recruiting and training of personnel, is considered too indirect, unless forming an integral part of a specific military operation. ${ }^{89}$

The ICRC also emphasizes the rule that civilians lose their immunity from attack only for so long as they directly participate in hostilities, stating that '[c]ivilians lose protection against direct attack for the duration of each specific act amounting to direct participation in hostilities'. ${ }^{90}$ However, the ICRC Guidance also states that ' $[\mathrm{m}]$ easures preparatory to the execution of a specific act of direct participation in hostilities, as well as the deployment to and the return from the location of its execution, constitute an integral part of that act' ${ }^{91}$ As such, a civilian will be participating directly in hostilities both during the commission of the act and for a certain period before and after the act is carried out.

The ICRC's concept of 'continuous combat function' may be criticized because of its lack of an authoritative basis in treaty law. However, it has the advantage of answering the question of who is a legitimate target by referring to activity that directly causes harm to belligerents and/or civilians. This

85 ibid 46.

86 ibid 46.

87 D Akande, 'Clearing the Fog of War? The ICR's Interpretive Guidance on Direct Participation in Hostilities' (2010) 59 ICLQ 180, 187.

88 ICRC, Interpretive Guidance (n 83) 53.

89 ibid.

90 ibid, 70. Certain States, including Israel and the US, have advocated a 'continuous direct participation' standard, arguing that the 'for such time' limit does not reflect what is required under customary international law. Such a view was rejected, however, by the Israeli Supreme Court: Public Committee Against Torture in Israel v Government of Israel, Supreme Court of Israel, HCJ 769/02 (13 Dec 2006) paras 12, 30.

91 ICRC, Interpretive Guidance (n 83) 65. 
provides some objective basis for determining who may be targeted. It is noteworthy that the ICRC's approach to the concepts of 'members of organised armed groups' and 'direct participation in hostilities' has been followed in recent State practice concerning drone attacks. ${ }^{92}$ Indeed, many would accept that members of an organized non-State armed group that is party to a non-international armed conflict are not to be regarded as civilians and are therefore not immune from attack.

However, the ICRC's 'continuous combat function' test has also been criticized for not going far enough, ${ }^{93}$ in the sense that it provides advantages to non-State groups as compared to State forces and thus promotes inequality between belligerents. ${ }^{94}$ There is an imbalance under the combined combat function approach since members of the State's armed forces without a combat role (with limited exceptions) are lawful targets, whereas their counterparts in non-State groups are not. Furthermore, since the continuous combat function is defined by reference to taking a direct part in hostilities, which is then itself narrowly defined, persons who join an organized armed group and perform military functions that do not constitute direct battlefield activity are exempt from targeting on the basis of status. It has therefore been suggested that an analogy should be drawn between members of regular armed forces and members of organized armed groups such that persons who perform the types of functions performed by members of the armed forces would not be considered a civilian. Although superficially attractive as it promotes equality of arms, the problem with this latter approach is that the functions performed by members of the regular armed forces are very broad indeed. Since non-State groups do not necessarily have formal indicia of membership, one would still need some criteria for identifying the membership of an organized armed group.

One of the critical questions with regard to targeted killing in any armed conflict is how to ensure that the persons being targeted are indeed legitimate targets. A loose test of membership of a group that cannot be applied on the basis of objective evidence is likely to lead to greater civilian casualties or at least a lack of public confidence in the operations. In all cases where a State uses lethal force against individuals in a non-international armed conflict there must be objective evidence to support the claim of membership of an armed group, or alternatively that the persons in question are taking a direct part in hostilities at that point in time. Furthermore, as noted above, where there is doubt as to whether a person is a civilian or is taking a direct part in hostilities, the person is to be presumed as protected from direct attack. ${ }^{95}$

Moreover, all feasible precautions must be taken in determining whether a person is a civilian, and, if so, whether the person is taking a direct part in

\footnotetext{
92 Decision of the German Federal Prosecutor of 20 June 2013, available at $<$ https://www. generalbundesanwalt.de/docs/drohneneinsatz_vom_04oktober2010_mir_ali_pakistan.pdf $\geq$.

93 See eg Watkin (n 83). $\quad 94$ ibid. ${ }_{95}$ Art 50(1) of Additional Protocol I of 1977.
} 
hostilities. ${ }^{96}$ This obligation requires parties to the conflict to use all information that is reasonably available in making the determination about whether a person is a lawful target. Where drones are used for targeting it could be argued that there is a greater degree of responsibility to take precautions than might otherwise be the case. This is because the technology and the way in which it is used in many cases make long-term surveillance possible. This means that more information is available about targets and more information can be made available than might otherwise be possible. Therefore, the assessment as to what information is reasonably available should take into account the relative ease with which information can be acquired.

It will not always be the case that evidence that a person is a member of an armed group or is directly participating in hostilities arises from information known about or which reveals the identity of the individual. In some cases, evidence about membership in an armed group or direct participation will arise from the characteristics associated with the individual or the activity that the individual is known to have performed or is performing. For example, where a non-State group has a particular uniform or insignia, evidence of membership may be derived from the wearing of that uniform or insignia. Strikes based on these 'signatures' or defining characteristics of an individual are not per se unlawful. What is crucial is whether the signatures or characteristics that are being used in making targeting decisions are the relevant characteristics as a matter of law. ${ }^{97}$ The characteristics must be relevant to a determination that a person is a member of an armed group or that the person is taking a direct part in hostilities. The information must be such as to provide a high degree of confidence that the legal tests have been satisfied.

A determination that individuals are military-age males in an area of known terrorist activity does not provide a high degree of confidence that the individual is either a member of an armed group or that the person is taking a direct part in hostilities at that particular time. Indeed, mere presence in a given locality can never, in itself, amount to direct participation in hostilities. Some specific act would need to be engaged in for the person to be considered to be taking a part in hostilities. Furthermore, the fact that a person is armed, even in areas that are known to contain terrorists, is not sufficient to constitute evidence of loss of civilian status or direct participation in hostilities. ${ }^{98}$ There are many parts of the world where it is lawful and/or common for individuals to carry personal arms. Carrying of such arms will not be sufficient to displace the presumption of civilian status. The public statements of States that they conduct threat assessments of individuals before targeting them in armed

96 ICRC, Interpretive Guidance (n 83) 74.

97 Heller (n 11) 94ff distinguishing between 'legally adequate' and 'legally inadequate' signatures.

98 See generally Heller (n 11); Prosecutor v Simić, IT-95-9-T, Trial Chamber, Judgment, 17 Oct 2003 , para 659 . 
conflict should be welcomed and should be urged, as this helps to raise the floor of protection with respect to legitimate targets. ${ }^{99}$ Of course, the situation must be correctly classified as an international or, as is more likely, a noninternational armed conflict; if the requirements posed for a NIAC are not met, a loose threat assessment is not enough, and the more rigorous conditions of self-defence under IHRL would then exclusively regulate who can be targeted.

Finally, even in cases where lethal force is targeted at a member of an organized armed group or a civilian directly participating in hostilities, any such strike would need to comply with the principle of proportionality, the second cardinal principle of targeting in IHL. Drones come from the sky, but they leave the heavy footprint of war on the communities they target. ${ }^{100}$ According to this principle, it is prohibited to carry out 'an attack which may be expected to cause incidental loss of civilian life, injury to civilians, damage to civilian objects, or a combination thereof, which would be excessive in relation to the concrete and direct military advantage anticipated'. ${ }^{101}$ By implication, where the use of force is not excessive, such losses are regarded as incidental damage and are not prohibited provided the IHL rules have been respected.

The risk to civilians may be exacerbated where drone strikes are carried out far away from areas of actual combat operations, especially in densely populated areas, where unsuspecting civilians may suddenly find themselves in the line of fire. Avoiding harm to civilians requires taking all feasible precautions to prevent or minimize incidental loss of civilian lives and to gather information relating to possible civilian casualties and military advantages that might result from the proposed operation. ${ }^{102}$

\section{The Possible Existence of an International Armed Conflict}

As noted above, where there is a conflict between a State and a non-State group, it may qualify as a non-international armed conflict (should the conditions for a NIAC be met). Drone strikes may also take place in circumstances where there is no NIAC between the State and the non-State group, because the criteria for the existence of a NIAC are not met. However, the absence of a non-international armed conflict between the State and the nonState armed group does not necessarily mean that IHL will not apply to the use of force by a State. This is because the use of lethal force by a State directed at an armed group may still be governed by the law relating to international armed conflicts.

\footnotetext{
$99<$ http://www.theguardian.com/world/2013/may/23/obama-drones-guantanamo-speech-text>.

100 Living Under Drones: Death, Injury, and Trauma to Civilians from US Drone Practices in Pakistan, available at <http://chrgj.org/wp-content/uploads/2012/10/Living-Under-Drones.pdf $>$.

101 Art 51(5)(b) of Additional Protocol I of 1977.

102 Art 57 of Additional Protocol I of 1977.
} 
As noted earlier, international armed conflicts are limited to conflicts between States. When a State carries out drone strikes on the territory of another State, it will either do so with the consent of the territorial State or without that consent. Where the force is used with the consent of the territorial State, there can only be a non-international armed conflict between the State and the group against whom force is used (or indeed no armed conflict at all). However, where force is used without the consent of the territorial State, one of the present authors has argued elsewhere (as have others and the ICRC) that there would be an international armed conflict between the State using force and the State on whose territory force is used. ${ }^{103}$ This would be an international armed conflict between the foreign State and the territorial State. This could be the case because the use of force by the intervening foreign State on the territory of the territorial State, without the consent of the latter, is a use of force against the territorial State. This, so the argument goes, is so even if the use of force is not directed against the governmental structures of the territorial State, or if the purpose of the use of force is not to coerce the territorial State in any particular way.

However, even on the view that there is an international armed conflict between the two States, such a conflict would exist in parallel with the noninternational armed conflict between the State and the non-State armed group that is being targeted, if the criteria for a NIAC were met. The two conflicts would thus exist simultaneously. With regard to targeting of the members of the non-State group, it would be the criteria discussed above from the law of non-international armed conflict that would be determinative of the legality of the targeting of such members. ${ }^{104}$ This is so because, as seen from the Tadić criteria discussed above, ${ }^{105}$ the hostilities between the State and nonState group constitute the essence of a non-international armed conflict. Failure to apply the law of non-international armed conflict to targeting of members of the group would in effect be a failure to recognize the noninternational armed conflict.

In cases where drone strikes occur outside the context of non-international armed conflicts and without the consent of the territorial State, on this view the individuals targeted would necessarily be classified as civilians, given that they would not constitute combatants in the international armed conflict

103 See eg Akande (n 59) 70-9 and Commentary on the First Geneva Convention: Convention (I) for the Amelioration of the Condition of the Wounded and Sick in Armed Forces in the Field, 2nd edition, 2016 (ICRC Commentary to GC I, 2nd edn), Commentary to art 2, paras 260-262.

104 Arguably, matters regarding detention of persons taken from the territory of the nonconsenting State or strikes that result in damage to objects or the natural environment would be governed by the law of international armed conflicts because, though those matters may be connected to the non-international armed conflict, the fact that they affect the territory of the State means they are also connected to the conflict between the two States.

105 See Tadić (n 60) para 70. 
between the two States. ${ }^{106}$ IHL prescribes that such persons would be protected from direct attack, ${ }^{107}$ unless and for such time as they take a direct part in hostilities. ${ }^{108}$ Drones strikes against them would, therefore, on this view only be lawful so long as they are directly participating in hostilities (on which, see above).

Finally, the fact that drone strikes would, according to this approach, take place in the context of an international armed conflict means that additional rules of international law to those discussed thus far would apply. For example, in addition to all the IHL obligations of the State using lethal force applying in such a situation, the applicable principles of international criminal law with respect to war crimes in an international armed conflict will also be relevant in determining individual responsibility for particular strikes. This conception of the relevant legal framework under IHL where drones are used abroad without the territorial State's consent thus has important implications both for substantive primary rules and for secondary rules on the responsibility of the actors involved.

\section{Does IHL Require a Capture Rather Than Kill Approach?}

Recent debates have raised the issue of whether IHL requires that a party to an armed conflict, under certain circumstances, considers the capture of an otherwise lawful target (i.e. a combatant, a member of an armed group with a CCF or a civilian directly participating in hostilities) rather than targeting with force. The ICRC has taken the view that it does, and in its Interpretive Guidance, it states that 'it would defy basic notions of humanity to kill an adversary or to refrain from giving him or her an opportunity to surrender where there manifestly is no necessity for the use of lethal force.' 109

The articulation of this principle has been controversial. ${ }^{110}$ It has been criticized for its alleged misrepresentation of the current lex lata, ${ }^{111}$ particularly on the basis that it suggests that the principle of military necessity sits above every rule of IHL in a limiting manner, rather than simply as a consideration that has already been factored into the rules. ${ }^{112} \mathrm{In}$ other words, so the argument goes, States have already decided that it is

\footnotetext{
106 Art 50(1) of Additional Protocol I I of 1977 (effectively defining civilians negatively, as all persons who are not combatants). $\quad 107$ Art 51(2) of Additional Protocol I of 1977.

108 Art 51(3) of Additional Protocol I of 1977. The Israeli Supreme Court has held that this constitutes a rule of customary international law and is therefore binding also on those States not party to API: Public Committee Against Torture in Israel v Government of Israel, Supreme Court of Israel, HCJ 769/02 (13 Dec 2006), para 30. ${ }_{109}$ ICRC, Interpretive Guidance (n 83) 82.

110 See Akande (n 87) 191.

111 See MN Schmitt, 'The Interpretive Guidance on the Notion of Direct Participation in Hostilities: A Critical Analysis' (2010) 1 Harvard National Security Journal 5, 39-43.

112 MN Schmitt, 'Military Necessity and Humanity in International Humanitarian Law: Preserving the Delicate Balance' (2010) 50 VaJIntlL 795, 835.
} 
necessary and proportionate to target combatants on the basis of their status, and in some cases, conduct alone.

It is too early to determine in which direction the controversy around this concept will be resolved. The impulse to move in the direction of the approach that in some cases capture rather than kill is required will likely continue in the context of modern anti-terrorism measures where individuals or small groups may be isolated in territory far away from the conflict zone, which may even be controlled by the State party or its allies. ${ }^{113}$ At least one State that uses drones has stated that, as a matter of policy, it will not use lethal force when it is feasible to capture a terror suspect. ${ }^{114}$ At the same time it should be remembered that drones by their very nature will in most cases not allow capture.

\section{E. Investigation and Accountability for Violations}

The modern concept of human rights is based on the fundamental principle that those responsible for violations must be held to account. A failure to investigate and where applicable punish those responsible for violations of the right to life in itself is increasingly understood to constitute a violation of that right. ${ }^{115}$ Legal, and indeed political, accountability are dependent on public access to the relevant information. ${ }^{116}$ Only on the basis of such information can effective oversight and enforcement take place. The first step towards securing human rights in this context is transparency about the use of drones. A lack of appropriate transparency and accountability concerning the deployment of drones undermines the rule of law and may threaten international security. ${ }^{117}$ Accountability for violations of IHRL (or IHL) is not a matter of choice or policy; it is a duty under domestic and international law'. 118

The various components of transparency ${ }^{119}$ require that the criteria for targeting and the authority which approves killings be known, and drone

113 R Goodman, 'The Power to Kill or Capture Enemy Combatants' (2013) 24 EJIL 819.

114 White House, Fact Sheet: U.S. Policy Standards and Procedures for the Use of Force in Counterterrorism Operations Outside the United States and Areas of Active Hostilities (23 May 2013).

${ }^{115}$ Kaya v Turkey, App No 22729/93, Judgement of 19 February 1998, paras 86-92; UNHRC, General Comment No 31 (2004) para 15; McCann and others v United Kingdom, App No 18984/91, Judgment of 27 September 1995, para 169.

116 See the UN Office of the High Commissioner for Human Rights, Principles on the Effective Prevention and Investigation of Extra-legal, Arbitrary and Summary Executions (recommended by the UN Economic and Social Council resolution 1989/65, 24 May 1989) para 16, and the companion UN Manual on the Effective Prevention and Investigation of Extra-legal, Arbitrary and Summary Executions (sometimes referred to as the 'Minnesota Protocol'). $\quad{ }^{117}$ Melzer (n 11) 4.

118 United Nations, Report of the Secretary-General's Panel of Experts on Accountability in Sri Lanka, 12 April 2011.

119 See P Alston, 'The CIA and Targeted Killings Beyond Borders' (2011) 2 Harvard National Security Journal 287. 
operations be brought within institutions which are able to disclose to the public the methods and findings of their intelligence, criteria used in selection of targets and precautions incorporated in such criteria. One of the criticisms levelled against the current drone programmes has been the absence of an official record regarding the persons killed. States must also give guarantees of nonrepetition of unlawful drone strikes and realize the right of victims to reparations.

Drone victims, like any other human rights victims, and the society at large, have a right to access information related to allegations of human rights violations and their investigations. ${ }^{120}$ Under IHRL, the UN Human Rights Committee has emphasized the need for transparency, highlighting victims' right to know the truth about the perpetrators, their accomplices and the motives thereof. ${ }^{121}$ Likewise, during an armed conflict, relatives of persons killed or missing have the right to know the fate of their relatives. ${ }^{122}$

A parallel obligation to investigate and where appropriate punish those responsible in respect of cases of alleged war crimes exists under IHL. ${ }^{123}$ Whenever there are reasons to query whether violations of IHL may have occurred in armed conflict as a result of a drone strike, such as the incorrect designation of persons as targetable, or disproportionate civilian harm, full adherence to accountability demands at least a preliminary investigation. ${ }^{124}$ Civilian casualties must be determined and should be disclosed.

\section{INTERNATIONAL HUMAN RIGHTS LAW}

\section{A. General Considerations}

The final substantive area that must be considered in assessing the legality of the use of armed drones under international law is international human rights law (IHRL). It is under IHRL that the right to life is most clearly protected, as set out in the various international and regional human rights treaties, ${ }^{125}$ and the rules

\footnotetext{
120 See the Case of Mapiripán Massacre v Colombia, Series C No 134, 15 September 2005, para 238.

121 Human Rights Council Resolution 9/11, Right to the truth, preamble para 1; General Assembly Resolution 61/177, art 24 (2); UN Commission on Human Rights, Resolution 2005/66.

122 Art 32 of Additional Protocol I of 1977; art 33 of Additional Protocol I of 1977; ICRC, 'Commentary to the Additional Protocols of 1977' (ICRC 1987) 350, para 1222; art 138 of the Fourth Geneva Convention of 1949.

123 See art 49 of the First Geneva Convention of 1949; art 50 of the Second Geneva Convention of 1949; art 129 of the Third Geneva Convention of 1949; art 146 of the Fourth Geneva Convention of 1949; art 85 of Additional Protocol of 1977; United Nations, Statute of International Criminal Tribunal for the former Yugoslavia, UN Doc S/RES/827 (1993) art 2; United Nations, Statute of the International Criminal Tribunal for Rwanda, UN Doc. S/RES/955 (1994) art 4; 1998 Rome Statute of the International Criminal Court, 2187 UNTS 90, art 8(2)(a).

124 Second Turkel Commission Report, 'The Public Commission to Examine the Maritime Incident of 31 May 2010' 256.

125 International Covenant on Civil and Political Rights (entered into force 23 March 1976) 999 UNTS 171 ('ICCPR') art 6(1); American Convention on Human Rights (entered into force 18 July
} 
of customary international law. ${ }^{126}$ The right to life is sometimes described as the 'supreme right'. ${ }^{127}$ Indeed, certain violations of the right to life are considered to be war crimes or crimes against humanity. ${ }^{128}$ As discussed in the next subsection, IHRL applies not only in peacetime but also in armed conflict, both international and non-international. As such, the right to life under human rights law forms the default legal norm applicable to the protection of people affected by drone strikes.

As a general rule, international human rights law requires that any deprivation of life must be non-arbitrary. ${ }^{129}$ The non-arbitrariness standard defining the scope of the right to life has generally been interpreted in human rights jurisprudence to require that intentional lethal force be used only as a last resort in order to protect life. ${ }^{130}$ Thus, Principle 9 of the UN Basic Principles on the Use of Force and Firearms by Law Enforcement Officials provides that 'intentional lethal use of firearms may only be made when strictly unavoidable in order to protect life'. Indeed, Article 2 of the European Convention on Human Rights (ECHR) contains, rather than a general prohibition of arbitrary deprivation of life, an exhaustive list of grounds on which it is permissible to use lethal force. ${ }^{131}$

Under IHRL, any force must be necessary, that is, the least harmful means of achieving the particular legitimate purpose of protecting life. Whether that is the case is a factual assessment. Other avenues should be explored first and only when they are shown to be inadequate can there be resort to force. ${ }^{132}$ Force must also be proportionate (that is, the potential harm in using force does not outweigh the legitimate protective goal pursued). This entails making a value judgement. It is important to note that proportionality in this human rights law sense is a different test to the principle of proportionality in IHL (on which, see above). Moreover, intentionally lethal or potentially lethal force can only be used where strictly necessary to protect against an imminent threat to life: '[T]he police may shoot to kill only when it is clear that an individual is about to kill someone (making lethal force proportionate) and

1978) OAS Treaty Series No 36 ('ACHR') art 4(1); art 4 of the African Charter on Human and Peoples' Rights; art 5 of the Arab Charter on Human Rights.

126 UNHRC, General Comment No 24, CCPR/C/21/Rev.1/Add.6, 10.

127 UNHRC, General Comment No 6: The Right to Life (1982) para 1.

128 See generally Prosecutor v Mrkšić et al. (2009) Appeals Judgement (IT-95-13/1-A).

129 See references above at n 129. Art 2 of the European Convention on Human Rights gives an exhaustive list of permissible grounds on which lethal force may be based.

${ }^{130}$ C Droege, 'Elective Affinities? Human Rights and Humanitarian Law' (2008) 90 IRRC 501, 525; D Kretzmer, 'Targeted Killing of Suspected Terrorists: Extra-Judicial Executions or Legitimate Means of Defence?' (2005) 16 EJIL 171, 179.

${ }^{131}$ Convention for the Protection of Human Rights and Fundamental Freedoms (entered into force 3 September 1953) 194 CETS (as amended) ('ECHR') art 2(2).

132 Art 3 of Code of Conduct for Law Enforcement Officials (General Assembly Resolution 34/ 169, annex, of 17 December 1979). 
there is no other available means of detaining the suspect (making lethal force necessary). ${ }^{\prime} 133$

Proper precautions must also be taken to prevent, where possible, the resort to force. In McCann and others $v$ UK, the European Court of Human Rights (ECtHR) held that the killing of members of the Provisional Irish Republican Army by State agents was a violation of their right to life as they could have been arrested on their arrival in Gibraltar, where the operation took place. ${ }^{134}$

Whether a particular drone strike satisfies these conditions must be examined on a case-by-case basis. It is important to emphasize, however, that, under these rules, alternatives to lethal force would need to be explored and shown to be inadequate for a drone strike to be lawful. In addition, it would need to be concluded that the use of lethal force is necessary on the basis that the person to be targeted constitutes an imminent threat to others. ${ }^{135}$ It is here that conflation of different legal standards across different regimes often poses problems. It is important not to confuse this imminence requirement in IHRL with similar conditions under the ius ad bellum. As discussed above, according to the doctrine of anticipatory self-defence, a State can use force against another State where there is an imminent threat of armed attack emanating from the latter State. This, however, is a different legal threshold to the imminence requirement in IHRL. Whether a particular transnational drone strike is lawful would depend on demonstrating imminence in both of these senses in cases where the attacking State is claiming a right of anticipatory self-defence. ${ }^{136}$

$133 \mathrm{~A} / \mathrm{HRC} / 14 / 24$, para 35.

134 McCann (n 115) paras 203-214; UNHRC, Suárez de Guerrero v Colombia, Merits (CCPR/C/ $15 / \mathrm{D} / 45 / 1979)$ para 13.2

135 See references to 'imminence' in the 2013 US Department of Justice White Paper, 'Lawfulness of a Lethal Operation Directed Against a U.S. Citizen Who Is a Senior Operational Leader of Al-Qa'ida or an Associated Force' (made public 5 February 2013) (although note the lack of clarity in the use of this requirement, discussed below) available at $<\mathrm{http}: / /$ msnbcmedia. msn.com/i/msnbc/sections/news/020413_DOJ_White_Paper.pdf>; White House, U.S. Policy Standards and Procedures for the Use of Force in Counterterrorism Operations Outside the United States and Areas of Active Hostilities, (23 May 2013) 2 ('... the United States will use lethal force only against a target that poses a continuing, imminent threat to U.S. persons') available at <http://www.whitehouse.gov/sites/default/files/uploads/2013.05.23_fact_sheet_ on_ppg.pdf >; see also the discussion of whether a US drone strike in Yemen fell foul of the arbitrary deprivation of life prohibition in IHRL, in N Lubell, Extraterritorial Use of Force Against Non-State Actors (OUP 2010) 174-8.

${ }_{136}$ The US White Paper on drones is an example where these categories of rules and the requirements under them are conflated, leading to an apparent misapplication of the imminence standard: see US Department of Justice White Paper, 'Lawfulness of a Lethal Operation Directed Against a U.S. Citizen Who is a Senior Operational Leader of Al-Qa'ida or an Associated Force' (made public 5 February 2013); see a discussion of the 'imminence' requirement in the White Paper in KJ Heller, 'The DOJ White Paper's Confused Approach Imminence (and Capture)' Opinio Juris (Blog), 5 February 2013. The UK's more recent change of policy in targeting British citizens abroad using drones who are thought to be affiliated with ISIS also suggests some conflation in the government's invocation of self-defence: E MacAskill, 'Drone Killing of British Citizens In Syria Marks Major Departure for UK', The Guardian, 7 September 2015. 


\section{B. Application of Human Rights in Armed Conflict}

It is now well established that IHRL continues to apply in time of armed conflict, alongside IHL. ${ }^{137}$ This has been confirmed in a number of decisions of the International Court of Justice (ICJ). ${ }^{138}$ Indeed, the general applicability of human rights obligations in armed conflict is confirmed by the presence of provisions relating to derogations in certain human rights treaties. Those provisions permit State parties to derogate in time of war or public emergency from some of their human rights obligations arising under those treaties. ${ }^{139}$ Such provisions confirm that, absent derogation, human rights obligations continue to apply in time of war or armed conflict. Thus, a State's conventional human rights obligations will only cease where that State validly suspends the rights in accordance with the treaty's derogation provisions. However, with the exception of the ECHR, the right to life is regarded as a non-derogable right under most major human rights treaties.

Where a particular drone strike falls within the context of an armed conflict, therefore, it will be governed by both IHL and IHRL. In certain cases, the right to life standard in IHRL might be interpreted in accordance with the relevant rules on the conduct of hostilities under IHL, explored above. Thus, the ICJ has stated that, while the right not arbitrarily to be deprived of one's life continues to apply in situations of armed conflict, what is an arbitrary deprivation of life under the ICCPR depends on the circumstances at hand and, in armed conflict, should be considered by reference to the IHL rules on the conduct of hostilities. ${ }^{140}$ According to this view, where a State targets an individual in a drone strike that falls within an armed conflict, whether that State has violated its obligation not arbitrarily to deprive that individual of their life depends on whether the State has acted consistently with those IHL rules discussed above.

However, the European Convention on Human Rights, as noted, does not express the right to life by reference to arbitrary deprivation of life. Rather, the ECHR provides for a closed list of permissible bases for depriving a person of their life. ${ }^{141}$ The extent to which one can read into this provision the IHL rules on the conduct of hostilities is, consequently, more limited than in the case of the arbitrariness standard found in the ICCPR and ACHR. ${ }^{142}$ However, it is important to note that the European Court of Human Rights has interpreted the right not to be deprived of one's liberty under Article 5 of the European Convention by reference to the IHL rules on detention in

137 For an overview of the trend towards the consensus that IHRL continues to apply in situations of armed conflict, see Droege (n 130) 503-9.

138 Legality of the Threat or Use of Nuclear Weapons (n 34) para 25; Legal Consequences of the Construction of a Wall in the Occupied Territory, Advisory Opinion [2004] ICJ Rep 136, para 106; DRC v Uganda (n 31) para $216 . \quad 139$ See eg art 4 ICCPR; art 15 ECHR; art 27 ACHR.

140 Legality of the Threat or Use of Nuclear Weapons (n 34) para 25. 141 Art 2(2) ECHR.

142 M Milanovic, Extraterritorial Application of Human Rights Treaties, Law, Principles and Policy (OUP 2011) 254ff. 
international armed conflicts. ${ }^{143}$ This was done despite the fact that the relevant provision, like the provision on the right to life, is not expressed by reference to arbitrary deprivation, but rather a closed list of permissible bases for deprivation of liberty. ${ }^{144}$ A similar interpretation of the right to life would allow the European Court to read the IHL rules on the conduct of hostilities into the right to life under the European Convention. In any case, Article 15 (2) ECHR permits derogation from this provision 'in respect of deaths resulting from lawful acts of war'. This provision should, therefore, be used where States consider it necessary to resort to more permissive rules of IHL.

Where a drone strike is conducted outside the context of an international or non-international armed conflict, IHL will not apply; in such situations, there can be no claim that a State's human rights obligations must be interpreted in accordance with IHL. Instead, those obligations will apply according to their ordinary meaning as developed in human rights jurisprudence. That said, the arbitrariness standard remains context-specific and indeed has been applied in ways that are realistic to the context. ${ }^{145}$ There are, however, limits to this. Importantly for our current enquiry, the view that mere past involvement in planning attacks is sufficient to render an individual targetable even where there is no evidence of a specific and immediate attack, distorts the requirements established in IHRL. ${ }^{146}$

The above discussion relates to the potential responsibility of the State using the drone. But what about the State on whose territory it is used? It should be remembered, as noted at the outset of this article, that States cannot consent to the violation of their IHL or IHRL obligations. A State that consents to the activities of another State on its territory remains bound by its own human rights obligations, including the obligations not actively to violate the rights of those within its jurisdiction itself, and also to ensure respect for human rights within its jurisdiction and thus to prevent violations of the right to life, including by other States operating on its territory, to the extent that it is able to do so. ${ }^{147}$

\section{Extraterritorial Application of the Right to Life}

The fact that drones have been used with lethal effects by States against individuals outside their territory raises the additional question of whether States can be held accountable, under those human rights treaties to which

\footnotetext{
143 See European Court of Human Rights, Hassan v United Kingdom, App No 29750/09, Grand Chamber Judgment, 16 September 2014.

${ }^{144}$ For a slightly critical reading of the judgment, see L Hill-Cawthorne, Detention in NonInternational Armed Conflict (OUP 2016) 158-9. $\quad{ }^{145}$ Melzer (n 11) 33.

146 US Department of Justice White Paper available at $<$ http://msnbcmedia.msn.com/i/msnbc/ sections/news/020413_DOJ_White_Paper.pdf>.

147 ILC, 'Articles on Responsibility of States for Wrongful Acts' (2001) UNYBILC vol II, Pt Two, art 23.
} 
they are party, for their extraterritorial actions. Reference was made earlier to the status of the right to life, and the prohibition of the arbitrary deprivation thereof, as a norm of customary international law. In its customary form, at least the negative obligation not arbitrarily to deprive someone of their life appears not to be limited to application within a State's territory. Indeed, the Universal Declaration of Human Rights does not contain a limitation clause on its geographical application and simply states that '[e]veryone has the right to life'. ${ }^{148}$

In addition, in certain circumstances, States are bound by those human rights treaties to which they are a party even in relation to conduct they take outside their territory. The fact that human rights treaty obligations can apply in principle to the conduct of a State outside its territory has been confirmed, inter alia, by the International Court of Justice, ${ }^{149}$ the UN Human Rights Committee, ${ }^{150}$ the Inter-American Commission on Human Rights ${ }^{151}$ and the European Court of Human Rights. ${ }^{152}$ The applicability of such treaties is normally limited to those individuals within the 'jurisdiction' of a State party. ${ }^{153}$ It is clear that all persons finding themselves within the territory of a State are presumed to be within its territorial jurisdiction. ${ }^{154}$ Moreover, it is clear from the case law that, where a State is exercising effective control over a part of another State's territory, the former will be exercising 'jurisdiction' such that its obligations under those human rights treaties to which it is a party will apply. ${ }^{155}$ Jurisdiction for the purposes of extraterritorial application of human rights treaties will additionally exist where, absent such territorial control, the State

\footnotetext{
148 Art 3 of the 1948 Universal Declaration on Human Rights.

149 Israeli Wall case (n 50) para 109.

150 Human Rights Committee, General Comment 31, CCPR/C/21/Rev.1/Add.13 (2004), para 10.

151 Coard et al. v United States, Case 10.951, Rep No 109/99, IACHR, 29 September 1999, para 37.

152 Al-Skeini v United Kingdom, App No 55721/07, Grand Chamber Judgment, 7 July 2011, paras 106-186; Loizidou v Turkey (1997) 23 EHRR 513; Ilascu v Moldoca and Russia (2005) EHRR 46, para 392; Al-Jedda v United Kingdom, App No 27021/08, 7 July 2011; Jaloud v Netherlands, App No 47708/08, Grand Chamber Judgment, 20 November 2014.

153 In art 2(1) ICCPR, the obligation of States is further limited to 'all individuals within its territory'. However, since Lopez Burgos v Uruguay, Communication 52/1979, Views, 29 July 1981, the Human Rights Committee has held that State parties can also be held accountable for violations outside their territory. This is to be contrasted with the view of the US and Israel, whereby those States reject the extraterritoriality of the ICCPR: HRC, 'Third Periodic Report: United States of America', CCPR/ C/ USA/ 3, 28 November 2005, 109-11; HRC, 'Second Periodic Report: Israel', CCPR/ C/ ISR/ 2001/ 2, 4 December 2001, [8]. Other States, such as the UK, disagree: HRC, 'Information Received from the United Kingdom of Great Britain and Northern Ireland on the Implementation of the Concluding Observations of the Human Rights Committee', CCPR/ C/ GBR/ CO/ 6/ Add.1, 3 November 2009, [24].

154 This presumption may be rebutted, however, where the State is unable to exercise its authority over its territory.

${ }^{155}$ See eg Human Rights Committee, General Comment 31, UN Doc CCPR/C/21/Rev.1/Add.13 (2004) para 10; Loizidou v Turkey, Preliminary Objections, 310 ECtHR, Series A, paras 62-64 (1995). See the discussion in Melzer (n 11) 155-67.
} 
exercises, through its agents, 'authority or control' over the specific individual abroad. ${ }^{156}$

One of the key difficulties posed by drones is that the attacking State can engage in targeted killing without exercising effective control over territory or without having the individual in custody, leading to questions over whether such persons fall within the 'jurisdiction' of the attacking State for the purposes of their human rights treaty obligations. There is limited case law on this matter. In the Alejandre case, the Inter-American Commission concluded that the shooting down of two private US registered air planes by Cuban military aircraft in international airspace violated the right to life of the passengers. ${ }^{157}$ At the same time, however, in Bankovic, the European Court held that persons killed during aerial bombings by NATO of a radio station in Serbia did not fall within the 'jurisdiction' of the participating States for the purposes of establishing whether they have violated the right to life. ${ }^{158}$ The broad sweep of this decision has, however, increasingly been narrowed in subsequent cases of the Court, ${ }^{159}$ and it is not clear that the position can be sustained. Indeed, the English High Court has held that 'whenever and wherever a state which is a contracting party to the [European] Convention [of Human Rights] purports to exercise legal authority or uses physical force, it must do so in a way that does not violate Convention rights'. ${ }^{160}$

It has been argued that the implication of this broader view of when an individual is within the jurisdiction of a State for the purposes of human rights treaties is that the deliberate killing of selected individuals through extraterritorial drone strikes is likely to bring the affected persons within the jurisdiction of the operating State. ${ }^{161}$ Pursuing this line of reasoning, where a State targets individuals abroad with lethal force, one can argue that it intends to exercise ultimate control over the individuals concerned, resulting in those actions being governed by the State's human rights treaty law obligations. ${ }^{162}$ Marko Milanovic is similarly of the view that the human rights treaty obligations of a State would apply to the deliberate killing of an individual through extraterritorial drone strikes. ${ }^{163}$ However, Milanovic's reasoning is

\footnotetext{
156 Ocalan v Turkey, App No 46221/99, Judgment, 12 March 2003, para 93; Issa and others $v$ Turkey, App No 31821/96, Judgment, 16 November 2004, para 71.

157 Alejandre Jr and others $v$ Republica de Cuba, Case 11.589, Rep No 86/99, IACHR, 29 September 1999, paras 23-25.

158 Bankovic and Others $v$ Belgium, App No 52207/99, Admissibility Decision, Grand Chamber, 12 December 2001, para 82. ${ }_{159}$ Al-Skeini (n 152) paras 106-186.

160 Al-Saadoon and others $v$ Secretary of State for Defence [2015] EWHC 715 (Admin) para 106. This aspect of the decision was overturned in the Court of Appeal on the grounds that though it might follow from the Al-Skeini decision of the European Court of Human Rights, it is up to the European Court, and not domestic courts, to take the decisive step in spelling out this consequence from its decision. For comment on the High Court decision, see DS Goddard, 'Applying the European Convention on Human Rights to the Use of Physical Force: Al-Saadoon' (2015) 91 International Law Studies 402.

162 See Droege (n 130); and Lubell (n 135) 227-31.

161 See Meltzer (n 11). 163 Milanovic (n 142) 209-21.
} 
that the negative obligations owed by States under IHRL, eg the obligation not arbitrarily to kill, should extend unbound by territorial constraints. This argument is based on the view that, in treaties that contain a jurisdiction clause, the negative obligation to respect rights is to be treated differently from the obligation to ensure those rights and that texts can and should be interpreted such that only the latter is confined to matters within the 'jurisdiction' of the State as that term has come to be interpreted. This appears to be a normatively desirable and principled basis for holding States to account in such situations, and it is in line with the position as set out above under customary international law. Importantly, to say that a State has human rights obligations with respect to conduct outside its territory does not, therefore, automatically mean that those obligations are the same as those that arise within its territory. ${ }^{164}$ In principle, while control of territory means that a State has obligations not only to respect but also to ensure and to fulfil the human rights of those on the territory guaranteed by international law, the exercise of authority with respect to an individual by State agents in the absence of territorial control at a minimum triggers the State's obligation to respect the rights of those individuals. ${ }^{165}$

It has been held that human rights treaties 'cannot be interpreted so as to allow a State party to perpetrate violations of [the treaty] on the territory of another State, which it could not perpetrate on its own territory'. ${ }^{166}$ The same must apply to the right to life under both custom and treaty law. In consequence, any positive action by a State, on its own territory or that of another State, should be carried out in compliance with its human rights obligations under both treaty and custom.

\section{CONCLUSION}

The legal framework for maintaining international peace and the protection of the right to life is a coherent and well-established system, reflecting norms that have been developed over the centuries and have withstood the test of time. Even though drones are not illegal weapons, they can easily be abused. The central norms of international law need not and should not be abandoned to meet challenges posed by terrorism and 'new' forms of conflict. On the contrary, the fact that drones make targeted killing so much easier should serve as a prompt to ensure a diligent application of these standards, especially in view of the likely expansion in the number of States with access to this technology in the future. The use of drones by States to exercise what is essentially a global policing function to counter potential threats presents a

164 See the ECtHR in Al-Skeini (n 156)152 at para 137, holding (contrary to the Bankovic decision) that "Convention rights can be "divided and tailored" on separating and tailoring obligations in extra-territorial contexts.'

166 Issa and others $v$ Turkey (n 156) para 71. 
danger to the protection of life, because the tools of domestic policing (such as capture) are not available, and the more permissive targeting framework of the law of armed conflict is often relied upon instead.

Though not inherently illegal weapons, drones do make the deployment of lethal force across borders much easier than before, and as such they pose significant risks to the protection of life. In this context the legal paradigm that is followed does make an important difference. If the assumption is that of a global non-international armed conflict, to which IHL applies as the dominant legal regime, then it becomes much easier to justify lethal force, than if one takes the default legal framework of IHRL as the governing regime. It was shown above that the notion of a global non-international armed conflict is controversial and in any event, the existence of any such conflict would have to be assessed against objective legal criteria rather than subjective self-interested claims. Moreover, even if IHL applies in a given situation, one should not be so quick to assume that IHL thereby modifies IHRL. ${ }^{167}$ The question must be also be asked in each case where armed drones are proposed to be used whether it is wise to do so, in addition merely to being legal. Such an approach is the only way in which force remains the exception, thereby protecting the right to life in the long term.

There is an urgent need for the international community to gain greater consensus on the interpretation of the constraints that international law in all its manifestations places on the use of drones. This is important not only because of the implications for those who currently find themselves on the receiving end of drones, but in order to keep a viable and strong system of international security intact. A central component of such a security system is the rule of law. Drones should follow the law, rather than the other way around.

The following fundamental principles should, it is proposed, form the starting point of a search for greater consensus on the regulation of armed drones:

a) The current international legal framework is adequate to govern drone strikes;

b) The right to life can only be adequately protected if all constraints on the use of lethal force abroad set out by international law are complied with individually and cumulatively, including the ius ad bellum, IHL (where applicable) and IHRL;

c) International norms on the use of lethal force must not be abandoned or modified to suit the current use of drones;

d) Any drone strike by a State outside of its own territory must comply with the ius ad bellum;

${ }^{167}$ L Hill-Cawthorne, 'Just Another Case of Treaty Interpretation? Reconciling Humanitarian Law and Human Rights Law in the ICJ' in M Andenas and E Bjorge (eds), A Farewell to Fragmentation: Reassertion and Convergence in International Law (CUP 2015). 
e) Where a drone strike takes place within international or noninternational armed conflict (a factual question governed by objective legal criteria), it is governed by both IHL and IHRL;

f) Outside of the narrow confines of international or non-international armed conflict, any killing is governed solely by IHRL and must meet that body of law's requirements of strict necessity and proportionality as those terms have been developed in human rights jurisprudence;

g) There should be transparency surrounding all drone operations to enhance accountability.

These are merely a starting point, but the current authors would contend that the international community has a strong interest in ensuring that there is clearer agreement on the basis of our common security. 